J. Dairy Sci. 96:3907-3915

http://dx.doi.org/10.3168/jds.2012-6207

(C) American Dairy Science Association ${ }^{\circledR}, 2013$.

\title{
Effects of urea formaldehyde condensation polymer treatment of flaxseed on ruminal digestion and lactation in dairy cows
}

\author{
A. Hawkins, ${ }^{\star}$ K. Yuan, ${ }^{\star}$ C. K. Armendariz, ${ }^{\star}$ G. Highland,† N. M. Bello,† T. Winowiski,‡ J. S. Drouillard, ${ }^{\star}$ \\ E. C. Titgemeyer, ${ }^{*}$ and B. J. Bradford ${ }^{* 1}$ \\ *Department of Animal Sciences and Industry, and \\ †Department of Statistics, Kansas State University, Manhattan 66506 \\ łLignoTech USA, Rothschild, WI 54474
}

\section{ABSTRACT}

Flaxseed is a potent source of the n-3 fatty acid $\alpha$-linolenic acid (ALA), yet most ALA is lost during ruminal biohydrogenation when ground flaxseed is fed to ruminants. Heat processing and urea formaldehyde condensation polymer (UFCP) treatment of flaxseed were investigated as possible means of protecting ALA from ruminal degradation. Ground flaxseed (GF), heated ground flaxseed (HGF), or UFCP-treated ground flaxseed (UFCPGF) were incubated for $0,4,8$, and $12 \mathrm{~h}$ in 4 ruminally cannulated multiparous lactating Holstein cows. Compared with GF, HGF and UFCPGF decreased ruminal disappearance of dry matter, crude protein, and ALA. Pepsin-digestible protein remaining after $12 \mathrm{~h}$ of ruminal incubation was greater for UFCPGF and HGF than for GF. Twenty-four lactating Holstein cows $(207 \pm 37 \mathrm{~d}$ in milk, $668 \pm 66 \mathrm{~kg}$ of body weight, and $1.33 \pm 0.56$ lactations) were then used in a randomized complete block design experiment with a basal feeding period to assess effects of flaxseed treatment on ALA enrichment of plasma and milk as well as lactational performance. No evidence existed that supplementation of HGF and UFCPGF affected dry matter intake, milk fat content, milk protein content, or energy-corrected milk yield, but UFCPGF marginally decreased milk yield compared with HGF. Plasma concentration of ALA was not affected by treatment. Concentrations of n-3 fatty acids and conjugated linoleic acids in milk fat were increased by UFCPGF relative to HGF, but ALA yield was not affected. Taken together, in situ results suggest that heat-treated flaxseed, with or without UFCP treatment, slowed ruminal disappearance of ALA. Feeding UFCP-treated flaxseed failed to alter ALA content of plasma or milk ALA yield relative to heating alone.

Key words: flaxseed, milk fatty acid, dairy cow

Received September 27, 2012

Accepted February 15, 2013.

${ }^{1}$ Corresponding author: bbradfor@ksu.edu

\section{INTRODUCTION}

The n-3 FA are essential for the normal physiological functions and health of humans and domestic animals (Palmquist, 2009). Dietary supplementation with $\alpha$-linolenic acid (ALA), a type of n-3 FA, has been shown to prevent cardiovascular diseases in humans (Bloedon and Szapary, 2004). In dairy cows, dietary supplementation of whole flaxseed, an oilseed rich in ALA, during the dry period decreased liver triacylglycerol accumulation after calving (Petit et al., 2007). In addition, feeding whole flaxseed, compared with feeding calcium salts of palm oil or micronized soybeans, decreased embryo mortality for cows that conceived within $120 \mathrm{~d}$ postpartum (Petit and Twagiramungu, 2006). Furthermore, whole flaxseed supplementation increased serum n-3 FA concentration and transiently reduced lymphocyte proliferation in postparturient cows, suggesting a role of flaxseed in modifying immune function in dairy cows (Lessard et al., 2003). Perhaps more interestingly, dietary supplementation of flaxseed to cattle has been investigated as a method to increase n-3 FA content in milk fat, for the purpose of improving human health (Petit, 2002, 2003; Côrtes et al., 2010). However, because flaxseed oil is extensively modified by ruminal biohydrogenation (BH), only small percentages of PUFA innate to flaxseed oil are absorbed by cattle and incorporated into milk (Lock and Bauman, 2004; Palmquist, 2009).

Chemical or physical (or both) treatments of oilseeds have been shown to slow ruminal BH of dietary PUFA (Palmquist, 2009) and protein degradation (Broderick and Craig, 1980). Both fat and protein constituents in lipid supplements treated with formaldehyde are highly protected from ruminal metabolism and are readily digested in the small intestine (Gulati et al., 2005). Tymchuk et al. (1998) reported that cattle consuming ground canola seed treated with formaldehyde had increased milk concentrations of PUFA, possibly as a result of reduced ruminal $\mathrm{BH}$. However, the optimum treatment levels of formaldehyde vary considerably, 
depending on the passage rate of the feed through the rumen, making it difficult to use formaldehyde effectively (Lebo and Winowiski, 2008). Recently, Lebo and Winowiski (2008) reported that treatment with a urea formaldehyde condensation polymer (UFCP) reduced in vitro ruminal degradation, but not intestinal digestibility, of protein from oilseeds. It is possible that UFCP treatment may provide superior protection of PUFA relative to existing technologies.

Two experiments were conducted with the objectives to (1) evaluate the effects of heating and UFCP treatment on nutrient digestion from flaxseed, (2) assess plasma and milk enrichment of n-3 FA in response to UFCP treatment versus heating of flaxseed, and (3) assess effects of UFCP treatment versus heating of flaxseed on lactational performance. We hypothesized that compared with heating alone, treating flaxseed with UFCP could better protect ALA from ruminal BH and subsequently increase plasma and milk concentrations of these bioactive lipids.

\section{MATERIALS AND METHODS}

The Kansas State University Institutional Animal Care and Use Committee (Manhattan) approved all experimental procedures.

\section{Ruminal Disappearance Experiment}

Four ruminally cannulated multiparous lactating Holstein cows $(120 \pm 10$ DIM, mean \pm SD $)$ were housed in individual tiestalls and fed a diet with no added fat (basal diet; Table 1) beginning $10 \mathrm{~d}$ before measures of ruminal nutrient disappearance.

Ground flaxseed (GF), heated ground flaxseed (HGF), and UFCP-treated ground flaxseed (UFCPGF; LignoTech USA, Rothschild, WI) were manufactured from a common flaxseed source. The composition of UFCP was reported in Lebo and Winowiski (2008). All flaxseed was coarsely ground; one aliquot was then heated to $100^{\circ} \mathrm{C}$ by direct addition of steam over a 4-min period and held at temperature for 16 min to produce the HGF. Another aliquot was used to manufacture UFCPGF using a 1:99 ratio of UFCP to GF with the same heating conditions as used for HGF. Samples ( $1 \mathrm{~g})$ of GF, HGF, and UFCPGF were weighed into Dacron bags $(5 \times 10 \mathrm{~cm}, 50-\mu \mathrm{m}$ pore size; Ankom Technology, Macedon, NY), placed in weighted mesh bags $(36 \times 42 \mathrm{~cm})$, and ruminally incubated in each of the 4 cannulated cows. Quadruplicate samples of GF, HGF, and UFCPGF were removed from each cow after 0 (5 min of soaking), 4,8 , or $12 \mathrm{~h}$ of ruminal incubation (Hussein et al., 1995), and placed in an ice bath until being rinsed (1-min agitation and 2-min spin, for
5 cycles) in a washing machine (Series 80 washing machine; Kenmore, Hoffman Estates, IL) with warm water $\left(30^{\circ} \mathrm{C}\right)$. Rinsed samples were subsequently dried $\left(55^{\circ} \mathrm{C}\right)$ in a forced-air oven for $72 \mathrm{~h}$. The $\mathrm{N}$ content of residue samples was determined by oxidation and detection of $\mathrm{N}_{2}$ (Midwest Laboratories Inc., Omaha, NE). In addition, pepsin-digestible protein content was determined in samples removed after $12 \mathrm{~h}$ of ruminal incubation (AOAC International, 1995; method 971.09).

\section{Lactation Experiment}

Twenty-four lactating Holstein cows $(207 \pm 37$ DIM, $668 \pm 66 \mathrm{~kg}$ of $\mathrm{BW}$, and $1.33 \pm 0.56$ lactations) were blocked by milk yield and randomly assigned to 1 of 2 diets. Prior to receiving dietary treatments, cows were fed a common basal diet with no added fat (basal diet; Table 1) for $21 \mathrm{~d}$. During this time, cows were housed in a group pen for $14 \mathrm{~d}$ and were moved to tiestalls on d 15 for the remainder of the experiment. Cows were milked 3 times daily $(0300,1100$, and $1900 \mathrm{~h}$ ) in a milking parlor and fed twice daily (0930 and $1800 \mathrm{~h}$ ) for ad libitum intake, targeting 5 to $15 \%$ daily refusals. Milk was sampled using in-line samplers and yields recorded at each milking on d 19 to 21 . Blood samples were collected before feeding on d $21(0930 \mathrm{~h})$ from the coccygeal vein or artery into $10-\mathrm{mL}$ evacuated tubes containing $\mathrm{K}_{3}$-EDTA (Vacutainer; Becton Dickinson, Franklin Lakes, NJ). Blood samples were centrifuged at $2,000 \times g$ for 15 min immediately after collection; plasma was harvested and frozen $\left(-20^{\circ} \mathrm{C}\right)$ until analysis.

Treating flaxseed with UFCP requires heating, and heating was shown in the ruminal experiment to alter the loss of ALA from flaxseed. Therefore, to carefully assess the effect of UFCP treatment per se, UFCPGF was compared with HGF in the lactation experiment. Cows were fed dietary treatments containing either HGF or UFCPGF (Table 1) for $21 \mathrm{~d}$ immediately following the 21-d basal feeding period. Feed offered and refused were measured daily, and feed ingredient and TMR samples were collected throughout the experimental period. Milk samples were collected at each milking on d 18 to 19, and blood samples were collected on d 21 as described for the basal period.

\section{Sample Analyses}

Milk samples were analyzed for concentration of fat, true protein, lactose (B-2000 Infrared Analyzer; Bentley Instruments Inc., Chaska, MN), MUN (MUN spectrophotometer; Bentley Instruments Inc.), and somatic cells (SCC 500; Bentley Instruments Inc.) by Heart of America DHIA (Manhattan, KS). Diet ingredients and 
Table 1. Ingredient and nutrient composition of the diets

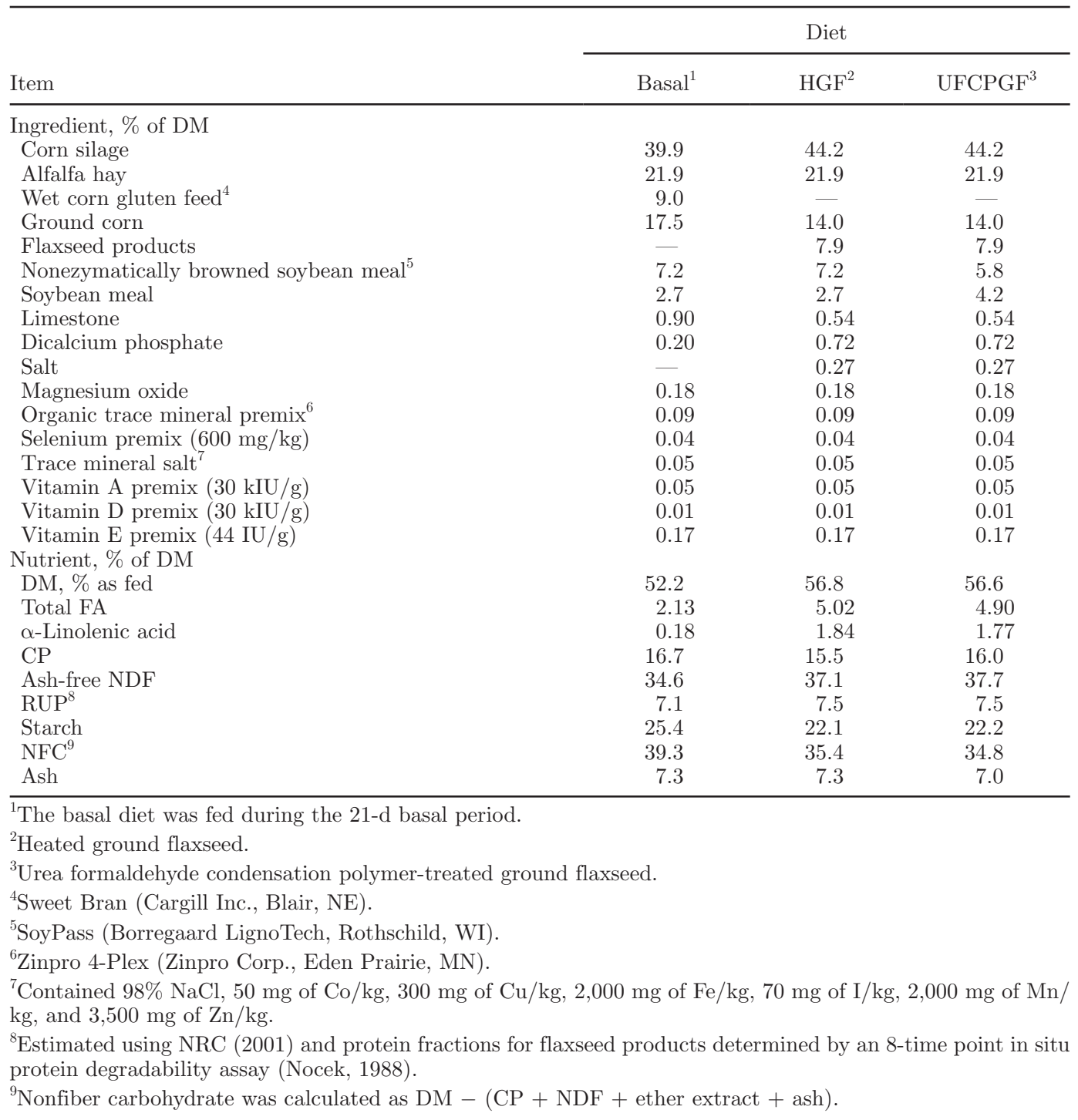

TMR samples were dried in a $55^{\circ} \mathrm{C}$ forced-air oven for $48 \mathrm{~h}$. Samples were composited for each period, ground to pass through a 1-mm screen, and analyzed for DM, $\mathrm{OM}, \mathrm{CP}, \mathrm{NDF}$, and starch. The DM content was determined by drying at $105^{\circ} \mathrm{C}$ in a forced-air oven for 16 $\mathrm{h}$. Ash concentration was determined after $4 \mathrm{~h}$ of oxidation at $500^{\circ} \mathrm{C}$ in a muffle furnace. Nitrogen content was determined by combustion (Leco Analyzer; Leco Corp., St. Joseph, MI), and CP was calculated as $\mathrm{N} \times$ 6.25. The concentration of NDF was determined using an Ankom Fiber Analyzer (Ankom Technology Corp., Fairport, NY), including amylase and sodium sulfite (Van Soest et al., 1991), and ash content of the NDF residue was determined for calculation of ash-free NDF. Starch was determined by $\alpha$-amylase and glucoamylase digestion, followed by colorimetric glucose quantifica- tion using a commercial kit (Autokit Glucose; Wako Chemicals USA Inc., Richmond, VA).

Milk samples for FA analysis were frozen $\left(-20^{\circ} \mathrm{C}\right)$ immediately after collection. Prior to FA analysis, milk samples were warmed to $39^{\circ} \mathrm{C}$, homogenized by shaking, and composited within cow for each period. A portion $(200 \mu \mathrm{L})$ of each composite milk sample and each plasma sample was lyophilized, resuspended in $1 \mathrm{~mL}$ of benzene containing methyl $\mathrm{C} 13: 0$ as an internal standard (91558; Supelco Inc., Bellefonte, PA), and methylated using $\mathrm{BF}_{3}$-methanol at $60^{\circ} \mathrm{C}$ for 60 min (Morrison and Smith, 1964). Composited feed and ruminally incubated samples (100 to $500 \mathrm{mg}$ ) were suspended in $2 \mathrm{~mL}$ of benzene containing methyl C13:0 as an internal standard, and methylated using methanolic $\mathrm{HCl}$ at $70^{\circ} \mathrm{C}$ for $2 \mathrm{~h}$ (Sukhija and Palmquist, 1988). The resulting FA 

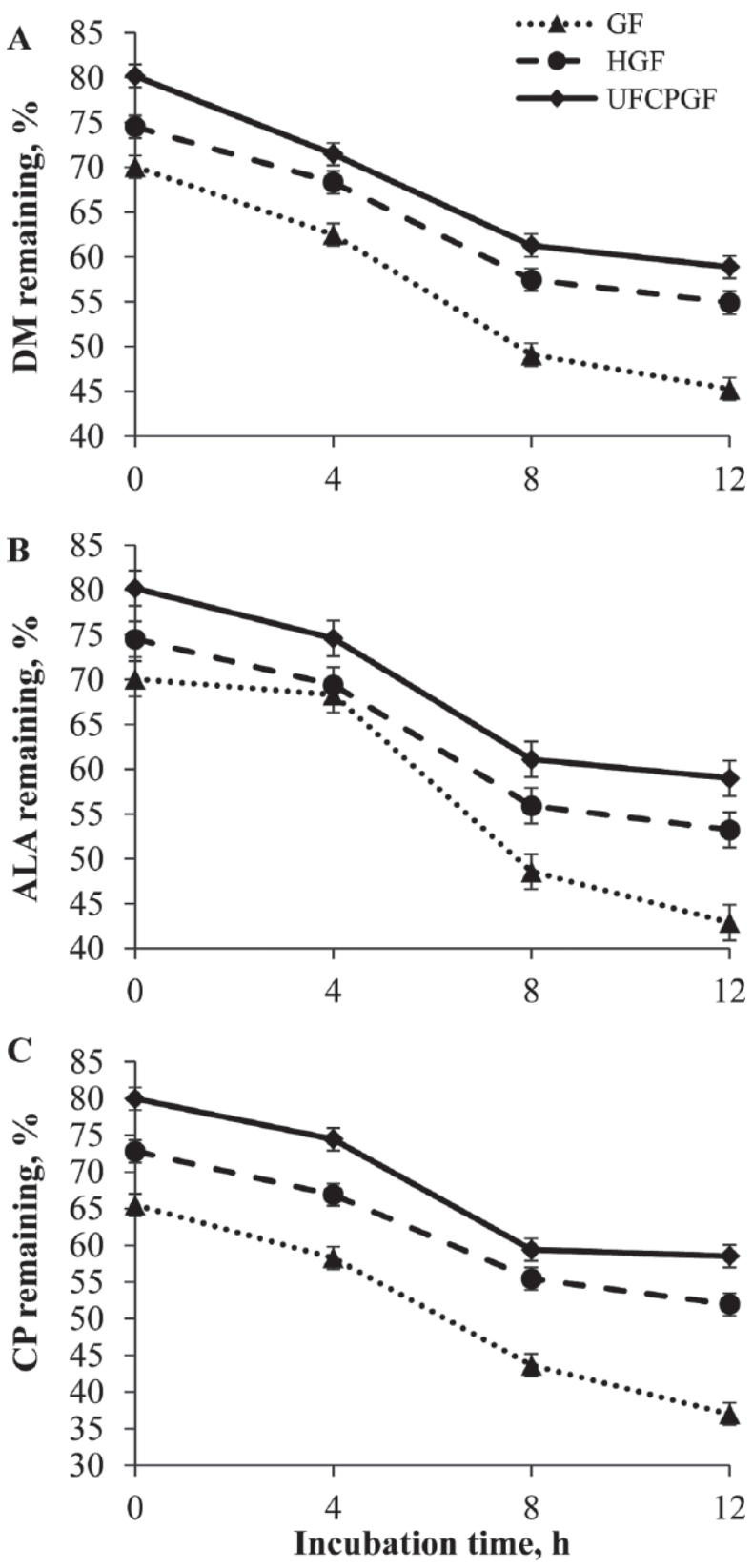

Figure 1. Effects of heat and urea formaldehyde condensation polymer (UFCP) on flaxseed DM, $\alpha$-linolenic acid (ALA), and CP remaining after $0,4,8$, or $12 \mathrm{~h}$ of ruminal incubation. Ground flaxseed $(\mathrm{GF})$, heated ground flaxseed $(\mathrm{HGF})$, and UFCP-treated ground flaxseed (UFCPGF) samples were incubated in the rumen for $0,4,8$, and $12 \mathrm{~h}$, and were analyzed to determine the amounts of DM, ALA, and $\mathrm{CP}$ remaining in bags relative to initial amounts. Values are least squares means \pm SEM $(\mathrm{n}=4)$. (A) For DM disappearance, treatment $(P<0.001)$ and time $(P<0.001)$ effects were significant, with no evidence for treatment $\times$ time interaction $(P=0.27)$. All treatments were significantly different from one another $(P<0.01)$. (B) For ALA disappearance, treatment $(P<0.001)$ and time $(P<0.001)$ effects were significant, with no evidence for treatment $\times$ time interaction $(P$ $=0.25)$. All treatments were significantly different from one another $(P<0.01)$. (C) For CP disappearance, treatment $(P<0.001)$ and time $(P<0.001)$ effects were significant, with no evidence for treatment $\times$ time interaction $(P=0.13)$. All treatments were significantly different from one another $(P<0.01)$. methyl esters were extracted in hexane and $1 \mu \mathrm{L}$ was injected into a SP-2560 capillary GC column (100 m × $0.25 \mathrm{~mm} \times 0.2 \mu \mathrm{m}$; Supelco Inc.) with a 1:100 split ratio and a carrier flow rate of $1 \mathrm{~mL}$ of $\mathrm{He} / \mathrm{min}$. Injection port and detector temperatures were $250^{\circ} \mathrm{C}$; the oven temperature increased from 140 to $200^{\circ} \mathrm{C}$ at $2^{\circ} \mathrm{C} / \mathrm{min}$ and then $4^{\circ} \mathrm{C} / \mathrm{min}$ to $245^{\circ} \mathrm{C}$ for a total run time of 67 min. Individual FA were identified and their response factors were calculated using a purchased FA methyl ester (FAME) standard (47885-U; Supelco Inc.). Recovery of ALA was assessed for each of the sample matrices used in this study. Composite samples of milk, plasma, and ruminal residue were randomly selected and spiked with additional ALA (L2376; Sigma-Aldrich, St. Louis, MO) in triplicate before processing. Milk samples were spiked with $31.5 \mu \mathrm{g}$ of ALA, plasma samples with 21 $\mu \mathrm{g}$ of ALA, and ruminal residue samples with $2.1 \mathrm{mg}$ of ALA. Recoveries of spiked ALA were $107.2 \pm 2.6 \%$ in milk, $95.7 \pm 20.9 \%$ in plasma, and $92.9 \pm 1.7 \%$ in ruminal residue (mean $\pm \mathrm{SD})$.

\section{Data Management and Statistical Analyses}

The residual weight of each nutrient component (DM, $\mathrm{CP}$, and ALA) after ruminal incubation was expressed as a percentage of initial component weight. With this method, component disappearance necessarily includes both degradation of the feedstuff and loss of small particles from the bags. Daily milk ALA yield was determined by multiplying milk yield by the concentration of ALA in milk. Energy-corrected milk was calculated as $0.327 \times$ milk yield $+12.86 \times$ fat yield $+7.65 \times$ protein yield. Total conjugated linoleic acid (CLA) content in milk fat was calculated as the sum of all detected CLA isomers (trans-9,trans-11, trans-10,cis-12, cis-9,trans-11, and cis-9,cis-11). The transfer efficiency of ALA added to the diet with the inclusion of flaxseed products was calculated for each cow according to the following formula: (milk ALA yield with flaxseed milk ALA yield during basal period) $\div$ (dietary ALA intake with flaxseed - dietary ALA intake during basal period). One HGF sample had inadequate mass for pepsin-digestible protein assay and was excluded from analysis. In addition, one cow on the HGF treatment in the lactation experiment had a dramatic decline in milk yield during the treatment period, and was identified as an outlier based on a Cook's D statistic of -4 ; results from this cow were excluded from analysis.

Data from the ruminal disappearance experiment were averaged across technical replicates before statistical analysis. Statistical models were fitted to each response variable of interest. The model included the fixed effects of treatment, time, and treatment $\times$ time interaction. Both cow and cow $\times$ treatment were in- 
Table 2. Protein and lipid composition of the flaxseed products

\begin{tabular}{lccc}
\hline & \multicolumn{3}{c}{ Flaxseed product } \\
\cline { 2 - 4 } Nutrient & $\mathrm{GF}^{1}$ & $\mathrm{HGF}^{2}$ & $\mathrm{UFCPGF}^{3}$ \\
\hline CP, \% of DM & 20.5 & 21.4 & $22.9^{4}$ \\
Pepsin-digestible protein, \% of CP & 91.2 & 93.2 & 87.7 \\
Total FA, \% of DM & 42.1 & 37.3 & 32.9 \\
FA, g/100 g of total FA & 5.7 & 5.9 & 5.9 \\
C16:0 & 4.0 & 4.1 & 4.0 \\
C18:0 & 18.9 & 18.8 & 0.75 \\
cis-9 C18:1 & 0.75 & 0.75 & 15.4 \\
cis-11 C18:1 & 15.2 & 15.6 & 53.7 \\
cis-9, cis-12 C18:2 & 54.1 & 53.7 & 0.17 \\
cis-9, cis-12,cis-15 C18:3 ( $\alpha$-linolenic acid) & 0.17 & 0.17 & 0.17 \\
C20:0 0.17 & 0.16 & 0.14 \\
cis-11 C20:1 & 0.19 & 0.20 & \\
C22:0 & 0.14 & 0.14 & \\
C24:0 0 & & & \\
${ }^{1}$ Ground flaxseed. & & & \\
${ }^{2}$ Heated ground flaxseed. & & & \\
${ }^{3}$ Urea formaldehyde condensation polymer-treated ground flaxseed. & & \\
${ }^{4}$ Included as much as 1.8\% CP (DM basis) from NPN. & & &
\end{tabular}

cluded as random effects in the model, the latter to recognize the experimental unit for treatment.

Data for the lactation experiment were analyzed by fitting statistical models to each response variable of interest. The model included the observed value of a given response variable during the basal period as a covariate in addition to the fixed effect of treatment. In all cases, the Satterthwaite method was used to estimate the degrees of freedom and the Kenward-Rogers approach was used for bias correction in standard error estimation. The Tukey-Kramer method was used to adjust for multiple comparisons and prevent inflation of type I errors when assessing simple treatment effects. For all analyses, significance was declared at $P \leq 0.05$ and marginal significance at $0.05<P \leq 0.10$. All statistical analyses were conducted using the GLIMMIX procedure of SAS (version 9.2; SAS Institute, Cary, NC).

\section{RESULTS AND DISCUSSION}

Results of the ruminal disappearance experiment are shown in Figure 1. No evidence of treatment $\times$ time interactions was observed for ruminal disappearance of
DM, ALA, and CP. Compared with GF, both HGF and UFCPGF had decreased $(P<0.01)$ disappearance of DM, ALA, and CP, regardless of the duration of ruminal incubation; the effect was greater for UFCPGF than HGF $(P<0.01)$. Consistent with our findings, Petit et al. (2002) reported that moist heat treatment at $100^{\circ} \mathrm{C}$ for 30 min decreased in vitro $\mathrm{DM}$ and $\mathrm{CP}$ degradation, and increased the RUP fraction of ground flaxseed. Heat treatment has been widely used to reduce the solubility of $\mathrm{CP}$ and increase the RUP fraction of various feedstuffs (Broderick and Craig, 1980). Heating feeds that contain reactive amines and free sugars may facilitate Maillard reactions (Adrian, 1974), leading to the formation of enzyme-resistant linkages that block protein cleavage sites, thus reducing the susceptibility of feed to proteolytic enzymes in the rumen (Broderick and Craig, 1980). Although this nonenzymatic browning process is most effective for feedstuffs with relatively high lysine content (i.e., soybean meal), heating also decreases in vitro ruminal degradability of lower-lysine feeds such as corn gluten meal, sunflower meal, and flaxseed meal (Coetzer, 2000).

Table 3. Effects of heat and urea formaldehyde condensation polymer on flaxseed CP remaining after $12 \mathrm{~h}$ of ruminal incubation, pepsin digestibility of 12 -h $\mathrm{CP}$ residue, and pepsin-digestible $\mathrm{CP}$ remaining

\begin{tabular}{|c|c|c|c|c|}
\hline Item & $\mathrm{GF}^{2}$ & $\mathrm{HGF}^{3}$ & $\mathrm{UFCPGF}^{4}$ & SEM \\
\hline $\mathrm{CP}$ remaining after $12 \mathrm{~h}$ of ruminal incubation, $\%$ of $\mathrm{CP}$ & $37.0^{\mathrm{a}}$ & $53.6^{\mathrm{b}}$ & $58.5^{\mathrm{b}}$ & 2.2 \\
\hline Pepsin digestibility, \% of CP remaining at $12 \mathrm{~h}$ & $70.6^{\mathrm{a}}$ & $81.1^{\mathrm{ab}}$ & $82.3^{\mathrm{b}}$ & 2.6 \\
\hline Pepsin-digestible $\mathrm{CP}$ remaining, $\%$ of original $\mathrm{CP}$ & $26.2^{\mathrm{a}}$ & $43.5^{\mathrm{b}}$ & $48.2^{\mathrm{b}}$ & 2.3 \\
\hline
\end{tabular}

\footnotetext{
$\overline{\mathrm{a}, \mathrm{b}}$ Treatments in the same row with different superscripts differ $(P<0.05)$.

${ }^{1}$ Values are $\operatorname{LSM} \pm$ average SEM ( $\mathrm{n}=3$ to 4$)$.

${ }^{2}$ Ground flaxseed.

${ }^{3}$ Heated ground flaxseed.

${ }^{4}$ Urea formaldehyde condensation polymer-treated ground flaxseed.
} 
Table 4. Dry matter intake, milk yield, and milk composition of lactating cows fed diets containing heated ground flaxseed (HGF) and urea formaldehyde condensation polymer-treated ground flaxseed (UFCPGF) ${ }^{1}$

\begin{tabular}{|c|c|c|c|c|}
\hline \multirow[b]{2}{*}{ Item } & \multicolumn{2}{|c|}{ Diet } & \multirow[b]{2}{*}{ SEM } & \multirow[b]{2}{*}{$P$-value } \\
\hline & HGF & UFCPGF & & \\
\hline DMI, $\mathrm{kg} / \mathrm{d}$ & 22.2 & 20.8 & 0.7 & 0.18 \\
\hline Milk yield, $\mathrm{kg} / \mathrm{d}$ & 28.3 & 25.4 & 1.1 & 0.08 \\
\hline $\mathrm{ECM}, \mathrm{kg} / \mathrm{d}$ & 31.2 & 28.8 & 1.1 & 0.15 \\
\hline ECM/DMI & 1.42 & 1.39 & 0.05 & 0.72 \\
\hline Fat, \% & 4.28 & 4.36 & 0.09 & 0.58 \\
\hline Protein, \% & 3.07 & 3.07 & 0.06 & 0.99 \\
\hline Lactose, \% & 4.83 & 4.81 & 0.03 & 0.67 \\
\hline MUN, mg/dL & 11.3 & 11.7 & 0.3 & 0.41 \\
\hline Milk protein/CP intake & 0.254 & 0.233 & 0.010 & 0.13 \\
\hline
\end{tabular}

${ }^{1}$ Values are LSM \pm average SEM $(\mathrm{n}=11$ to 12$)$.

Lebo and Winowiski (2008) suggested that, with moist heating, UFCP solution penetrates to the center of flaxseed particles and provides uniform protection throughout the particle. Our results indicate that UFCP treatment protected DM, ALA, and CP from ruminal disappearance more effectively than steamheating alone, although the magnitude of the difference was small. Unexpectedly, heating and especially UFCP treatment appeared to decrease the FA content of GF (Table 2). It is unclear how these FA were lost or became undetectable in the processed GF products, but it is possible that lipid complexes were formed, which made the FA resistant to the methylation step required for gas chromatographic analysis of FA. The possibility that some lipid was lost during grinding cannot be ruled out, although this would have had to affect HGF

Table 5. Fatty acid composition of total plasma lipids from lactating cows fed heated ground flaxseed (HGF) or urea formaldehyde condensation polymer-treated ground flaxseed (UFCPGF) ${ }^{1}$

\begin{tabular}{|c|c|c|c|c|}
\hline $\mathrm{FA}, \mu \mathrm{g} / \mathrm{mL}$ & \multicolumn{2}{|c|}{ Diet } & SEM & $P$-value \\
\hline C14:0 & 13.3 & 12.2 & 0.50 & 0.12 \\
\hline $\mathrm{C} 16: 0$ & 251.5 & 239.1 & 8.1 & 0.30 \\
\hline cis-9 C16:1 & 39.0 & 34.2 & 1.53 & 0.04 \\
\hline C17:0 & 14.7 & 14.8 & 0.82 & 0.93 \\
\hline trans-10 C18:1 & 1.92 & 1.44 & 0.45 & 0.46 \\
\hline trans-11 C18:1 & 10.9 & 11.3 & 0.73 & 0.68 \\
\hline cis-9 C18:1 & 173.6 & 161.1 & 7.0 & 0.22 \\
\hline cis-11 C18:1 & 13.5 & 12.5 & 0.56 & 0.23 \\
\hline cis-9,cis-12 C18:2n-6 & 980.9 & 946.1 & 44.0 & 0.58 \\
\hline cis-9,trans-11 C18:2 CLA $^{2}$ & 2.66 & 2.62 & 0.26 & 0.92 \\
\hline cis-6,cis-9,cis-12 C18:3n-6 & 18.9 & 16.8 & 1.32 & 0.28 \\
\hline cis-5,cis-8,cis-11,cis-14,cis-17 C20:5n-3 (eicosapentaenoic acid) & 24.9 & 23.1 & 1.24 & 0.33 \\
\hline $\mathrm{C} 22: 0$ & 3.76 & 4.24 & 0.35 & 0.34 \\
\hline cis-7, cis-10,cis-13, cis-16, cis-19 C22:5n-3 & 24.6 & 25.4 & 1.47 & 0.70 \\
\hline 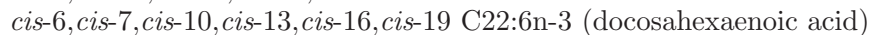 & 1.28 & 1.10 & 0.44 & 0.78 \\
\hline Total n- $3^{3}$ & 375 & 376 & 22 & 0.97 \\
\hline Total n- $6^{4}$ & 1,082 & 1,122 & 49 & 0.56 \\
\hline n-6-to-n-3 ratio & 2.96 & 2.90 & 0.05 & 0.38 \\
\hline
\end{tabular}

\footnotetext{
${ }^{1}$ Values are LSM \pm average SEM $(\mathrm{n}=11$ to 12$)$.

${ }^{2} \mathrm{CLA}=$ conjugated linoleic acid.

${ }^{3} \mathrm{C} 18: 3 \mathrm{n}-3+\mathrm{C} 20: 5 \mathrm{n}-3+\mathrm{C} 22: 5 \mathrm{n}-3+\mathrm{C} 22: 6 \mathrm{n}-3$.

${ }^{4} \mathrm{C} 18: 2 \mathrm{n}-6+\mathrm{C} 18: 3 \mathrm{n}-6+\mathrm{C} 20: 2 \mathrm{n}-6+\mathrm{C} 20: 3 \mathrm{n}-6+\mathrm{C} 20: 4 \mathrm{n}-6$.
} 
Table 6. Milk FA profile of lactating cows fed heated ground flaxseed (HGF) and urea formaldehyde condensation polymer-treated ground flaxseed (UFCPGF) ${ }^{1}$

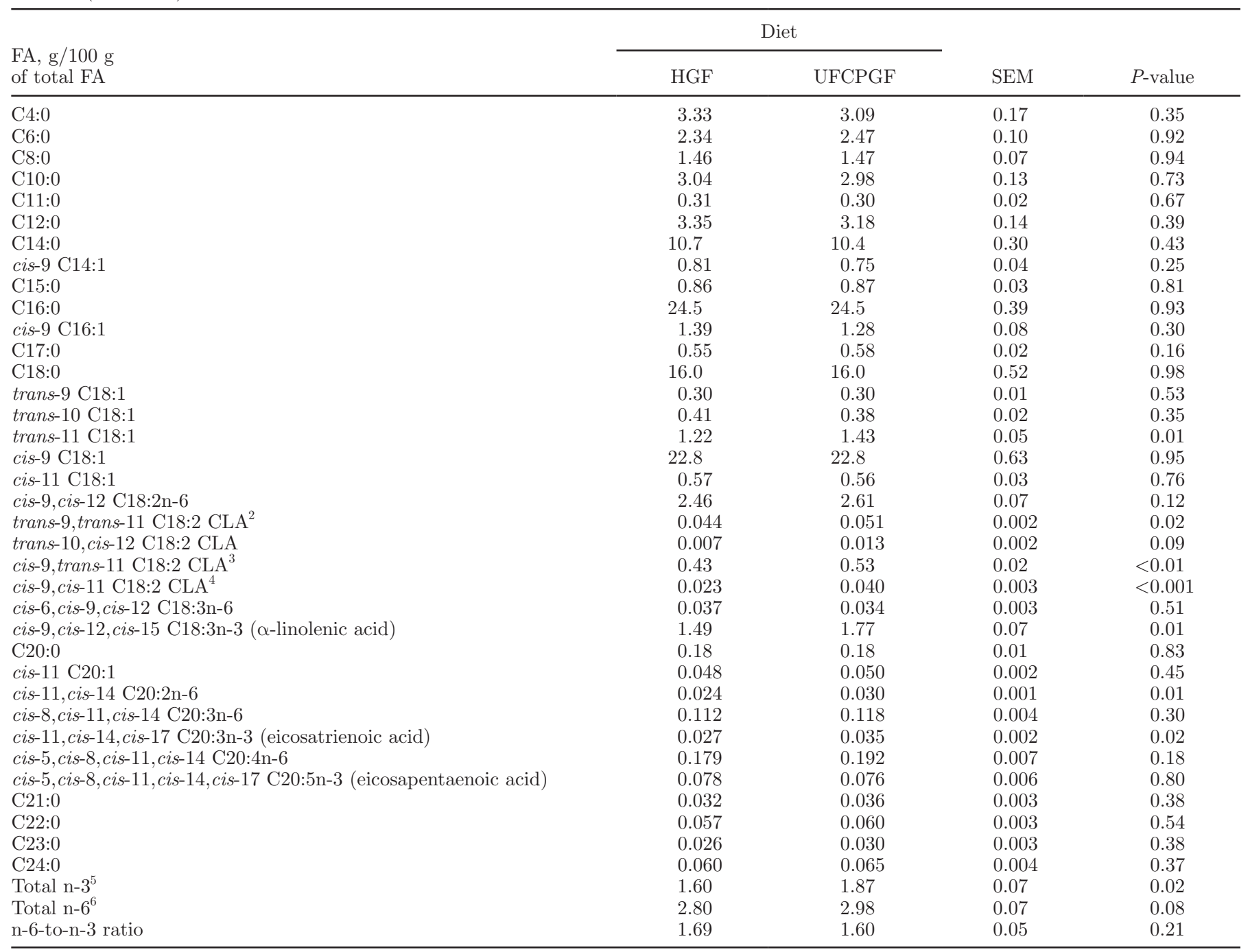

${ }^{1}$ Values are LSM \pm average SEM ( $\mathrm{n}=11$ to 12$)$.

${ }^{2} \mathrm{CLA}=$ conjugated linoleic acid.

${ }^{3}$ May also include small quantities of trans-7,cis-9 CLA and trans-8,cis-10 CLA.

${ }^{4}$ May also include trans-11, cis-13 CLA.

${ }^{5} \mathrm{C} 18: 3 \mathrm{n}-3+\mathrm{C} 20: 3 \mathrm{n}-3+\mathrm{C} 20: 5 \mathrm{n}-3$.

${ }^{6} \mathrm{C} 18: 2 \mathrm{n}-6+\mathrm{C} 18: 3 \mathrm{n}-6+\mathrm{C} 20: 2 \mathrm{n}-6+\mathrm{C} 20: 3 \mathrm{n}-6+\mathrm{C} 20: 4 \mathrm{n}-6$.

and UFCPGF to a greater extent than GF to explain the differences in lipid content between products. A third possibility is that flaxseed treatments rendered the particles less accessible to the benzene solvent used for extraction before FA methylation.

Treatments that protect protein from ruminal degradation may also render the protein indigestible throughout the gastrointestinal tract; however, to serve as a valuable source of RUP, a protein must be susceptible to postruminal proteolysis. To assess whether UFCP treatment altered protein digestibility, residues from the 12 -h in situ time point were subjected to pepsin digestion. Compared with GF, UFCPGF had greater pepsin digestibility of $12-\mathrm{h} \mathrm{CP}$ residue and both HGF and UFCPGF had more pepsin-digestible CP remaining (Table 3). The improved pepsin digestibility of CP residue from UFCPGF compared with GF may reflect enrichment of the most indigestible proteins in the GF samples due to extensive ruminal degradation of the digestible fraction. Nevertheless, our results are consistent with the hypothesis that UFCP binds proteins in flaxseed to form a protective barrier against modification of lipids by ruminal microflora, but allows for postruminal digestion (Lebo and Winowiski, 2008). 
In short, both heating and UFCP treatment improved ruminal stability of flaxseed protein without inhibiting its potential for postruminal digestion. Nevertheless, it should be noted that no in situ or in vitro methods can completely replicate the digestive environment in the ruminant gastrointestinal tract.

Results for production responses in the lactation experiment are shown in Table 4. Dry matter intake was not significantly different between HGF and UFCPGF, but milk yield was marginally less for UFCPGF than HGF. No evidence for treatment effects was observed for milk fat, protein, or lactose content, nor were treatment effects detected for yield of ECM or ECM efficiency (ECM/DMI). Neither the ratio of milk true protein to CP intake nor MUN were significantly affected by treatment, providing no evidence of differences in MP supply; nor were differences expected, as diets were balanced for predicted RUP supply (Table 1).

Results for plasma FA concentrations are shown in Table 5 and milk FA profiles in Table 6. Little evidence existed of treatment effects on plasma FA, except for cis-9 C16:1 concentration, which was significantly less for UFCPGF relative to HGF. This finding is unlikely to signify a critical metabolic response, given the number of plasma FA evaluated and the lack of significant treatment effects on any other plasma FA measured. Despite the limited evidence for treatment effects on plasma FA, treatments did influence milk FA profile. Compared with HGF, UFCPGF increased ALA $(P=$ $0.01)$, eicosatrienoic acid $(P=0.02)$, and total n-3 FA $(P=0.02)$ as a proportion of FA in milk. Interestingly, the proportion of vaccenic acid (trans-11 C18:1) was increased by UFCPGF, as were the proportions of detected CLA isomers. Total CLA proportion was increased by UFCPGF from 0.50 to $0.62 \pm 0.02$ (SEM) $\mathrm{g} / 100 \mathrm{~g}$ of FA $(P<0.01)$. Although not measured directly, our results suggest an alteration in $\mathrm{BH}$ dynamics in cows fed UFCPGF compared with HGF. One possible explanation is that the decrease in lipid release from UFCPGF (Figure 1) may have limited BH, resulting in greater ruminal outflow of both ALA and products of its incomplete $\mathrm{BH}$. Because 70 to $90 \%$ of the cis-9,trans-11 CLA present in milk fat originates from the conversion of vaccenic acid by mammary tissue $\Delta^{9}$-desaturase (Lock and Bauman, 2004), an increased supply of vaccenic acid for UFCPGF likely accounts for most of the CLA response.

Results for milk ALA yield are shown in Figure $2 \mathrm{~A}$, and there was no treatment difference between UFCPGF and HGF. Because ALA intake was less for UFCPGF than HGF (360 vs. $401 \pm 11 \mathrm{~g} / \mathrm{d} ; P<0.01$ ), we attempted to determine if the efficiency of ALA transfer from feed to milk was higher for UFCPGF
A
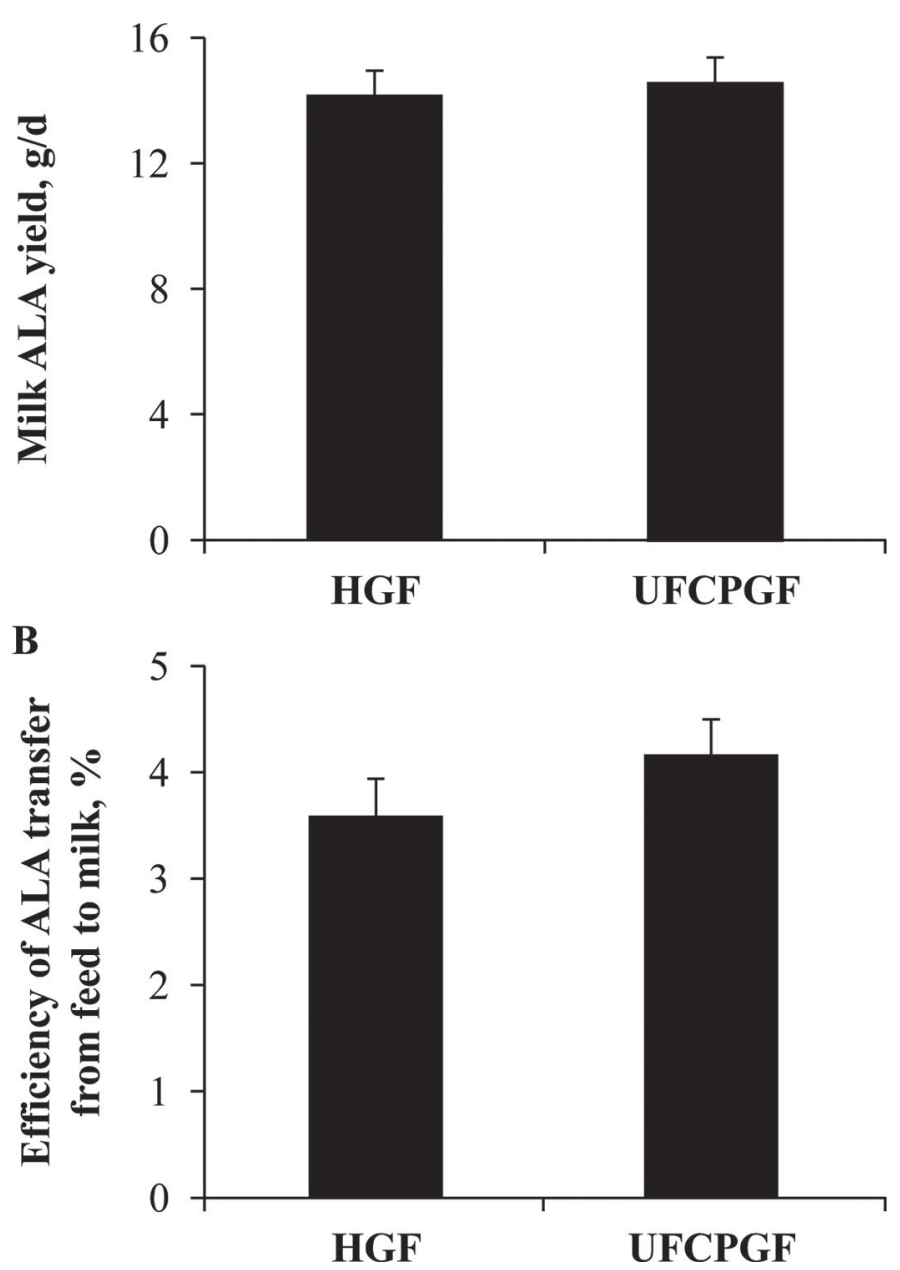

Figure 2. Effects of dietary treatments on milk $\alpha$-linolenic acid (ALA) yield, and efficiency of ALA transfer from feed to milk in cows fed heated ground flaxseed (HGF) or urea formaldehyde condensation polymer-treated ground flaxseed (UFCPGF). Values are least squares means \pm SEM ( $\mathrm{n}=11$ to 12 ). (A) Milk ALA yield; no evidence was found for a treatment effect $(P=0.67)$. (B) Efficiency of ALA transfer from feed to milk; no evidence was found for a treatment effect $(P=$ $0.11)$.

than HGF, but results (Figure 2B) did not show a difference between the treatments.

\section{CONCLUSIONS}

Compared with GF, both UFCPGF and HGF provided greater protection of DM, ALA, and CP from in situ ruminal degradation. In the lactation experiment, we found no evidence for differences in DMI, ECM yield, milk fat content, and milk protein content between UFCPGF and HGF. Neither milk ALA yield nor milk n-6-to-n-3 FA ratio was significantly altered by UFCPGF compared with HGF, but total milk fat 
n-3 and CLA contents were greater for UFCPGF than HGF. In summary, we found little evidence that UFCP treatment of flaxseed improved ALA transfer to plasma or milk compared with heating alone.

\section{ACKNOWLEDGMENTS}

The authors acknowledge LignoTech USA (Rothschild, WI) for partial financial support of this research. We are grateful to Derek Brake at Kansas State University (Manhattan) for critical comments on the manuscript. This paper is contribution no. 12-464-J from the Kansas Agricultural Experiment Station (Manhattan).

\section{REFERENCES}

Adrian, J. 1974. Nutritional and physiological consequences of the Maillard reaction. World Rev. Nutr. Diet. 19:71-122.

AOAC International. 1995. Official Methods of Analysis. 16th ed. AOAC International, Arlington, VA.

Bloedon, L. T., and P. O. Szapary. 2004. Flaxseed and cardiovascular risk. Nutr. Rev. 62:18-27.

Broderick, G. A., and W. M. Craig. 1980. Effect of heat treatment on ruminal degradation and escape, and intestinal digestibility of cottonseed meal protein. J. Nutr. 110:2381-2389.

Coetzer, C. M. 2000. Manipulation of ruminal protein degradability. PhD Diss. Kansas State Univ., Manhattan.

Côrtes, C., D. C. da Silva-Kazama, R. Kazama, N. Gagnon, C. Benchaar, G. T. D. Santos, L. M. Zeoula, and H. V. Petit. 2010 Milk composition, milk fatty acid profile, digestion, and ruminal fermentation in dairy cows fed whole flaxseed and calcium salts of flaxseed oil. J. Dairy Sci. 93:3146-3157.

Gulati, S. K., M. R. Garg, and T. W. Scott. 2005. Rumen protected protein and fat produced from oilseeds and/or meals by formaldehyde treatment; their role in ruminant production and product quality: A review. Aust. J. Exp. Agric. 45:1189-1203.

Hussein, H. S., M. R. Cameron, G. C. Fahey Jr., N. R. Merchen, and J. H. Clark. 1995. Influence of altering ruminal degradation of soybean meal protein on in situ ruminal fiber disappearance of forages and fibrous byproducts. J. Anim. Sci. 73:2428-2437.
Lebo, S. E., Jr., and T. S. Winowiski, inventors. 2008. Bypass protection for protein and starch in animal feed. LignoTech USA Inc., assignee. Patent International Publication No. WO 2008/079942:A1.

Lessard, M., N. Gagnon, and H. V. Petit. 2003. Immune response of postpartum dairy cows fed flaxseed. J. Dairy Sci. 86:2647-2657.

Lock, A. L., and D. E. Bauman. 2004. Modifying milk fat composition of dairy cows to enhance fatty acids beneficial to human health. Lipids 39:1197-1206.

Morrison, W. R., and L. M. Smith. 1964. Preparation of fatty acid methyl esters and dimethylacetals from lipids with boron fluoridemethanol. J. Lipid Res. 5:600-608.

Nocek, J. E. 1988. In situ and other methods to estimate ruminal protein and energy digestibility: A review. J. Dairy Sci. 71:20512069 .

NRC. 2001. Nutrient Requirements of Dairy Cattle. 7th rev. ed. Natl. Acad. Sci., Washington, DC.

Palmquist, D. L. 2009. Omega-3 fatty acids in metabolism, health, and nutrition and for modified animal product foods. Prof. Anim. Sci. 25:207-249.

Petit, H. V. 2002. Digestion, milk production, milk composition, and blood composition of dairy cows fed whole flaxseed. J. Dairy Sci. $85: 1482-1490$

Petit, H. V. 2003. Digestion, milk production, milk composition, and blood composition of dairy cows fed formaldehyde treated flaxseed or sunflower seed. J. Dairy Sci. 86:2637-2646.

Petit, H. V., M. F. Palin, and L. Doepel. 2007. Hepatic lipid metabolism in transition dairy cows fed flaxseed. J. Dairy Sci. 90:47804792.

Petit, H. V., G. F. Tremblay, E. Tremblay, and P. Nadeau. 2002. Ruminal biohydrogenation of fatty acids, protein degradability, and dry matter digestibility of flaxseed treated with different sugar and heat combinations. Can. J. Anim. Sci. 82:241-250.

Petit, H. V., and H. Twagiramungu. 2006. Conception rate and reproductive function of dairy cows fed different fat sources. Theriogenology 66:1316-1324.

Sukhija, P. S., and D. L. Palmquist. 1988. Rapid method for determination of total fatty acid content and composition of feedstuffs and feces. J. Agric. Food Chem. 36:1202-1206.

Tymchuk, S. M., G. R. Khorasani, and J. J. Kennelly. 1998. Effect of feeding formaldehyde- and heat-treated oil seed on milk yield and milk composition. Can. J. Anim. Sci. 78:693-700.

Van Soest, P. J., J. B. Robertson, and B. A. Lewis. 1991. Methods for dietary fiber, neutral detergent fiber, and nonstarch polysaccharides in relation to animal nutrition. J. Dairy Sci. 74:3583-3597. 